\title{
Zmiany informacji w ewidencji gruntów i budynków a proces wymiaru podatku od nieruchomości, rolnego i leśnego
}

\section{Data changes in the land and buildings registry in the process of determining the property, agricultural and forestry tax}

Streszczenie. Celem powyższego tekstu jest przedstawienie roli ewidencji gruntów i budynków w procesie określania należności podatnika z tytułu podatku od nieruchomości, rolnego i leśnego oraz wskazanie na tym gruncie najważniejszych problemów związanych z zmianą danych w niej zawartych. Podstawą opracowania będzie analiza przepisów, orzecznictwa sądów administracyjnych oraz praktyka funkcjonowania ewidencji.

Słowa kluczowe: ewidencja gruntów i budynków; podatki; podatek od nieruchomości.

\begin{abstract}
The purpose of this article is to present the role of the land and buildings registry in the process of determining the taxpayer's receivables from real estate, agricultural and forest tax, and an indication of the most important problems on the ground of data changes in it. This will be based on the analysis of the
\end{abstract}


regulations, court decisions and administrative practices of the functioning of the records.

Keywords: registry of land and buildings; taxes; real estate tax.

\section{Uwagi wstępne}

Funkcjonowanie jednostek samorządu terytorialnego (dalej: j.s.t.), oraz wykonywanie przez nie zadań publicznych ${ }^{1}$ wiąże się z wydatkowaniem środków pieniężnych. Na gruncie ustawy zasadniczej j.s.t. przyznany został udział w dochodach publicznych w stopniu odpowiednim do przypadających im zadań ${ }^{2}$. Tymi dochodami publicznymi są w pierwszej kolejności przymusowe, bezzwrotne, ogólne świadczenia pieniężne pobierane od mieszkańców j.s.t. oraz podmiotów mających siedzibę na jej terenie. Świadczenia te powinny być uiszczane w razie zaistnienia stanu faktycznego przewidzianego $\mathrm{w}$ przepisach prawnych. Zagwarantowana tym samym została przewaga dochodów publicznoprawnych, czyli kreowanych na podstawie ustaw, w stosunku do dochodów prywatnoprawnych, które j.s.t. mogą uzyskiwać w drodze stosunków cywilnych ${ }^{3}$.

Dochody j.s.t. w głównej mierze opierają się o wpływy z podatków dochodowych oraz majątkowych ${ }^{4}$. W 2014 r. dochody budżetów samorządowych z tytułu podatków dochodowych od osób fizycznych i prawnych wyniosły łącznie ponad 42\% ogółu dochodów j.s.t., natomiast z tytułu podatków od majątku nieruchomego prawie $22 \%{ }^{5}$. Tymi podatkami są:

1 Art. 163 Konstytucji Rzeczypospolitej Polskiej z dnia 2 kwietnia 1997 r. (Dz.U. Nr 78 poz. 483 ze zm., dalej: Konstytucja).

Art. 167 ust. 1 Konstytucji.

3 W. Miemiec, Finanse samorzqdu terytorialnej w nowej Konstytucji Rzeczypospolitej Polskiej, „Finanse Komunalne” 1997, nr 5, s. 9.

4 Zob. szerzej na temat podatków majątkowych A. Borodo, Podatki majątkowe w Polsce - zagadnienia ogólne, [w:] H. Dzwonkowski, J. Głuchowski, A. Pomorska (red.), W kręgu prawa podatkowego i finansów publicznych. Księga dedykowana Profesorowi Cezaremu Kosikowskiemu w 40-lecie pracy naukowej, Lublin 2005, s. 47-55.

5 Główny Urząd Statystyczny, Gospodarka finansowa jednostek samorzq̨du terytorialnego 2014, Warszawa 2015, tabl. 8, s. 31. 
podatek rolny ${ }^{6}$, leśny ${ }^{7}$ i od nieruchomości ${ }^{8}$. Dla gmin, czyli podstawowych jednostek samorządu terytorialnego ${ }^{9}$, wpływy z podatków od majątku nieruchomego stanowią prawie 1/3 wszystkich dochodów ${ }^{10}$.

Funkcjonowanie podatków rolnego, leśnego i od nieruchomości jest uzależnione od zaistnienia stanów prawnych i faktycznych, na podstawie których uwarunkowane jest powstanie zobowiązania podatkowego ${ }^{11}$. Stany te to, co do zasady, posiadanie określonej nieruchomości, będącej przedmiotem opodatkowania $^{12}$. Do określania stanu posiadania nieruchomości służyć ma ewidencja gruntów i budynków, zwana dalej ewidencją, która jest urzędowym źródłem informacji w sprawach natury administracyjnej, czyli także w sprawach podatkowych, i ma nadrzędne znaczenie w stosunku do informacji złożonych przez podatnika ${ }^{13}$.

Jeśli informacje zawarte w ewidencji gruntów i budynków pozostają jednak w sprzeczności z danymi zamieszczonymi w innych rejestrach publicznych, których pierwszeństwo wynika z regulujących ich prowadzenie przepisów, dopuszczalne jest odstępstwo od związania wpisami zawartymi w ewidencji gruntów i budynków ${ }^{14}$. Ewidencja gruntów i budynków jest instytucją funkcjonującą na styku prawa administracyjnego, finansowego oraz cywilnego.

Przedmiotem niniejszego opracowania jest analiza przepisów regulujących funkcjonowanie ewidencji przy określaniu zobowiązania podatkowego w zakresie niektórych podatków oraz dotyczącego tej

$6 \quad$ Reguluje go ustawa z dnia 15 listopada 1984 r. o podatku rolnym (tekst jedn. Dz.U. z 2016 r., poz. 617, dalej: u.p.r.).

7 Określony w ustawie z dnia z dnia 30 października 2002 r. o podatku leśnym (tekst jedn. Dz.U. z 2016 r., poz. 374, dalej: u.p.l.).

8 Został on unormowany w art. 2-7a ustawy z dnia 12 stycznia 1991 r. o podatkach i opłatach lokalnych (tekst jedn. Dz.U. z 2016 r., poz. 716 ze zm., dalej: u.p.o.l.).

Art. 164 ust. 1 Konstytucji.

10 Główny Urząd Statystyczny, Gospodarka finansowa..., tabl. 26, s. 62.

11 K. Ostrowski, Prawo finansowe. Zarys ogólny, Warszawa 1970, s. 146-147 oraz A. Hanusz, Podatek od nieruchomości, [w:] A. Hanusz (red.), Źródła finansowania samorzqdu terytorialnego, Warszawa 2015, s. 46-47.

12 E. Chojna-Duch, Kształtowanie podstawy opodatkowania podatkiem od nieruchomości, „Samorząd Terytorialny” 1992, nr 3, s. 10-16.

13 Teza 1 wyroku WSA w Łodzi z dnia 30 października 2013 r., I SA/Łd 667/13, LEX nr 1473982.

14 Wyrok NSA z dnia 19 listopada 2015 r., II FSK 2365/13, LEX nr 1990271. 
ewidencji orzecznictwa. Analiza ta pozwoli na zweryfikowanie tezy, że ewidencja gruntów i budynków w swojej obecnej formie jest narzędziem, które powinno zostać poddane reformie i przebudowie na gruncie normatywnym.

\section{Prawne ramy funkcjonowania ewidencji}

Ewidencja gruntów i budynków to obejmujący obszar całego kraju jednolity i systematycznie aktualizowany zbiór informacji o gruntach, budynkach i lokalach, ich właścicielach oraz o innych osobach fizycznych lub prawnych władających tymi gruntami, budynkami i lokalami ${ }^{15}$. Podstawą prawną jej funkcjonowania jest rozdział 4 ustawy Prawo geodezyjne i kartograficzne ${ }^{16}$ oraz akty wykonawcze ${ }^{17}$. Podmiotem odpowiedzialnym za prowadzenie ewidencji jest starosta lub prezydent miasta na prawach powiatu właściwy miejscowo dla obszaru ewidencji ${ }^{18}$. Wskazuje się w niej informacje dotyczące gruntów ${ }^{19}$, budynków ${ }^{20}$ i lokali ${ }^{21}$. Obok tego znajdują się tam także dane dotyczące podmiotów, określające właścicieli nieruchomości ${ }^{22}$, miejsce ich stałego pobytu ${ }^{23}$. Ponadto $\mathrm{w}$ ewidencji wskazuje się dane o ewentualnym wpisie nieruchomości do rejestru zabytków ${ }^{24}$, objęciu szczególną formą ochrony przyrody ${ }^{25}$, wartości kata-

. Baran, Prawo cywilne dla zarzqdców nieruchomości, Warszawa 2009, s. 178.

Art. 20-26 ustawy z dnia 17 maja 1989 r. Prawo geodezyjne i kartograficzne (tekst jedn. Dz.U. z 2015 r., poz. 520 ze zm., dalej: u.p.g.k.).

17 Rozporządzenie Ministra Rozwoju Regionalnego i Budownictwa z dnia 29 marca 2001 r. w sprawie ewidencji gruntów i budynków (tekst jedn. Dz.U. z 2015 r., poz. 542 ze zm., dalej: Rozporząazenie ws. ewidencji).

Art. 22 ust. 1 u.p.g.k.

Art. 20 ust. 1 pkt 1 u.p.g.k.

Art. 20 ust. 1 pkt 2 u.p.g.k.

Art. 20 ust. 1 pkt 3 u.p.g.k.

Art. 20 ust. 2 u.p.g.k.

Art. 20 ust. 2 pkt 2 u.p.g.k.

Art. 20 ust. 2 pkt 3 u.p.g.k. Szczegółowe regulacje dotyczące wpisu do rejestru zabytków określone zostały w art. 8-14 ustawy z dnia 23 lipca 2003 r. o ochronie zabytków i opiece nad zabytkami (tekst jedn. Dz.U. z 2014 r., poz. 1446 ze zm.). Decyzję o wpisie do rejestru wydaje wojewódzki konserwator zabytków, czyli organ administracji rządowej. 
stralnej $^{26}$ i zobowiązaniach dotyczących dzierżawy w przypadku gruntów rolnych $^{27}$.

Dane zawarte $\mathrm{w}$ ewidencji są podstawą oznaczenia nieruchomości w księdze wieczystej oraz służą do określania zobowiązań podatkowych. Rola ewidencji została wskazana bezpośrednio w u.p.l. i u.p.r. Jednak w u.p.o.l. brak jest bezpośredniego odniesienia do ewidencji gruntów i budynków, lecz mowa jest o ewidencji podatkowej nieruchomości. W związku z tym w celu określenia wymiaru podatku od nieruchomości zapisy w ewidencji gruntów i budynków mają drugorzędne znaczenie, a determinantem wymiaru podatku od nieruchomości jest wystąpienie zdarzenia, z którym ustawa wiąże powstanie obowiązku podatkowego ${ }^{28}$.

Właściciele i osoby władające gruntami mają obowiązek zgłaszania staroście wszelkich zmian dotyczących danych objętych ewidencją ${ }^{29}$. Wnioskować o zmianę w ewidencji nie mogą jednak osoby trzecie w stosunku do nieruchomości ${ }^{30}$.

W przypadku danych zawartych w ewidencji istnieje domniemanie powszechnej znajomości przez podatników danych zawartych w rejestrze ze względu na jego jawność. Wprowadzenie tego rodzaju domniemania to zastosowanie zasady ignorantia legis non excusat, czyli nieznajomość prawa nie jest usprawiedliwieniem, a tym samym stanowi podtrzymanie fikcji powszechnej znajomości prawa ${ }^{31}$. Zaznaczyć jednak należy, że tyl-

25 Art. 20 ust. 2 pkt 4 u.p.g.k. Chodzi o formy ochrony wymienione w art. 6 ust. 1 pkt 1-9 ustawy z dnia 16 kwietnia 2004 r. o ochronie przyrody (tekst jedn. Dz.U. z 2015 r., poz. 1651 ze. zm.).

26 Art. 20 ust 2 pkt 5 u.p.g.k., szerzej na ten temat zob. P. Borkowski, Kataster nieruchomości, [w:] P. Borkowski, Notarialne poświadczenie dziedziczenia, Warszawa 2011.

27 Art. 20 ust. 2 pkt 6 u.p.g.k.

28 P. Banasik, A. Sarna, Opodatkowanie podatkiem od nieruchomości dróg wewnętrznych, „Przegląd Podatkowy” 2007, nr 11, s. 43-48.

29 B. Baran, Prawo cywilne dla zarzq̨dców..., s. 179.

30 Wyrok WSA w Gorzowie Wielkopolskim z dnia 10 grudnia 2015 r., II SA/Go 908/15, LEX nr 1945007.

31 Zob. Uchwała TK z dnia 7 marca 1995 r., W 9/94, gdzie TK wskazał że „Funkcjonowanie prawa, zwłaszcza w demokratycznym państwie prawnym, opiera się na założeniu, że wszyscy adresaci obowiązującej normy prawnej - a więc zarówno podmioty obowiązane do jej przestrzegania, jak i organy powołane do jej stosowania znają jej właściwą treść (tzw. fikcja powszechnej znajomości prawa) i że nikt nie może 
ko informacje o charakterze przedmiotowym dotyczące nieruchomości są jawne i powszechnie dostępne na żądanie każdego, tj. bez konieczności wykazywania interesu prawnego. Dane o charakterze podmiotowym i przedmiotowo-podmiotowym, z uwagi na ochronę danych osobowych, mogą być udzielane tylko z uwzględnieniem ograniczeń wskazanych w przepisach szczegółowych ${ }^{32}$.

Rola ewidencji przy określaniu zobowiązania fiskalnego podatnika jest duża, ponieważ od informacji w niej zawartych zależy rodzaj obciążenia podatkowego (podatkiem rolnym, leśnym lub od nieruchomości). Dane zawarte w ewidencji umożliwiają obliczenie wysokości należności podatkowej, zgodnie z regułą: powierzchnia razy stawka podatku (związana $\mathrm{z}$ oznaczeniem rodzaju nieruchomości w ewidencji) $)^{33}$.

\section{Zmiany zapisów w ewidencji przez organ ją prowadzący a zmiany dotyczące wymiaru podatków}

Istnienie narzędzia, jakim jest ewidencja gruntów i budynków, wymaga nieustannej aktualizacji danych, prowadzi jednocześnie do powstawania licznych wątpliwości oraz nieścisłości przy określaniu należności podatkowej.

Jednym z głównych problemów, jakie są widoczne w funkcjonowaniu ewidencji, jest zmiana zapisów w niej zawartych. Regulacje ustawowe stanowią, że korekta informacji zawartych w ewidencji nie może nastąpić bez ingerencji z strony właściciela lub posiadacza nieruchomości. Jednakże w przepisach wykonawczych, tj. w Rozporządzeniu ws. ewidencji,

uchylić się od ujemnych skutków naruszenia tej normy na tej podstawie, że normy tej nie znał lub rozumiał ją opacznie”.

Potwierdza to teza wyroku WSA w Kielcach z dnia 22 kwietnia 2015 r. II SA/Ke 213/15, LEX nr 1760236, jednak w przypadku, gdy podmiot posiada interes prawny, może uzyskać informacje podmiotowe lub podmiotowo-przedmiotowe, patrz: wyrok WSA w Gorzowie Wielkopolskim z dnia 26 listopada 2015 r., II SA/Go 621/15, LEX nr 1942931.

33 B. Rogalska, Podatkowe rejestry podmiotowe o charakterze podstawowym, [w:] B. Rogalska, Podatkowe rejestry podmiotowe w polskim systemie prawnym, Warszawa 2014, s. 289-290. 
organowi prowadzącemu ewidencję, czyli staroście lub prezydentowi miasta na prawach powiatu, wyznaczone zostało zadanie okresowej weryfikacji danych zawartych $\mathrm{w}$ ewidencji ${ }^{34}$ oraz dokonywania aktualizacji danych, czyli utrzymania ewidencji w zgodności z dostępnymi dla organu dokumentami i materiałami źródłowymi ${ }^{35}$. W orzecznictwie sądów administracyjnych wskazuje się, że właściwe organy zobowiązane są podjąć działania niezbędne do zaktualizowania ewidencji w przypadku stwierdzenia jej nieaktualności ${ }^{36}$. Powtórna ocena dokumentów i materiałów źródłowych możliwa jest jednak tylko w ramach prowadzonego z urzędu

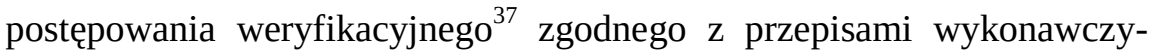
$\mathrm{mi}^{38}$. Prowadzenie ewidencji koncentruje się na dwóch aspektach. Pierwszy z nich to udzielanie informacji organom uprawnionym (w przypadku podatków - organom podatkowym), a drugi to ciągła aktualizacja w operacie ewidencyjnym zbioru informacji podmiotowych i przedmiotowych o gruntach. Przez aktualizowanie należy rozumieć także usuwanie błędnych wpisów ${ }^{39}$.

Weryfikacja danych powinna zostać wykonana co najmniej raz na 15 lat lub w przypadku, gdy wyjdą na jaw istotne nieprawidłowości w dotychczasowym prowadzeniu ewidencji. Odpowiedzialne są za nią organy prowadzące ewidencję. W praktyce oceny stanu faktycznego, tj. sprawdzenia dokumentacji oraz dokonania oceny faktycznej, dokonują pracownicy urzędu podległego organowi, czyli starostwa powiatowego lub urzędu miasta na prawach powiatu. Osoby te, tworzące zawiązywane na tę okoliczność komisje, występują w zależności służbowej w stosunku do swojego pracodawcy, od którego otrzymali polecenie weryfikacji stanu faktycznego. Powierzenie tego rodzaju uprawnień osobom podległym organowi może budzić wątpliwości co do ich obiektywności. Dotyczyć to może przypadku starostw ziemskich, na terenie których znajdują się gmi-

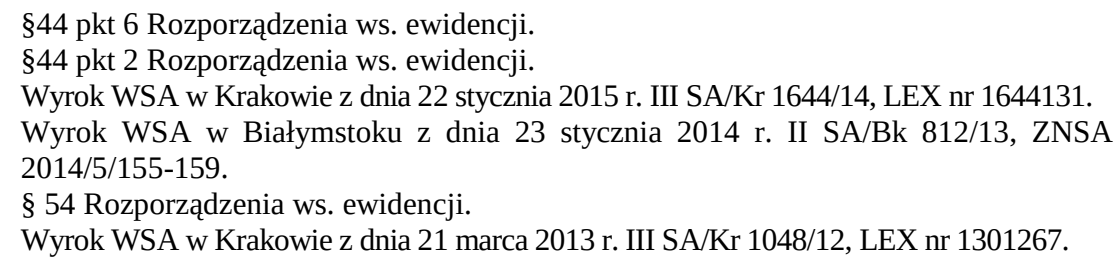


ny (do kas których trafiają podatki obliczane na podstawie danych z ewidencji). Prowadzenie ewidencji przez prezydentów miast na prawach powiatu, którzy są równocześnie organami podatkowymi dla podatków od nieruchomości, rolnego i leśnego, oraz dokonywanie zmian w ewidencji za pośrednictwem pracowników samorządowych znajdujących się w zależności służbowej od prezydentów może budzić kontrowersje ${ }^{40}$. Zachodzi bowiem sytuacja, w której organ, który wyznacza podstawę opodatkowania, może ją zmieniać, czyli jest sędzią we własnej sprawie.

W literaturze przedmiotu i orzecznictwie odnaleźć można tezę, że dane zawarte w ewidencji są podstawą wymiaru podatku, jednak tylko w przypadku, gdy są one zgodne z rzeczywistym stanem faktycznym i prawnym ${ }^{41}$. Na bazie tego można stwierdzić, że podatek, który został uregulowany przez podatnika, ale był obliczony błędnie, powinien być podatkiem nienależnym organowi podatkowemu. Odnosząc się do tego należy wskazać, że dla ustalenia wysokości zobowiązania podatkowego nadrzędną zasadą jest pojęcie prawdy materialnej, określonej w art. 122 Ordynacji podatkowej $^{42}$. To na organach prowadzących postępowanie podatkowe spoczywa obowiązek podjęcia wszelkich niezbędnych działań w celu dokładnego wyjaśnienia stanu faktycznego oraz załatwienia sprawy $^{43}$. Wnioskować z tego można, że pomimo błędnego i niewłaściwego prowadzenia ewidencji przez starostów, to na wójtach i burmistrzach zajmujących się wymiarem podatków i będących organami podatkowymi ciąży obowiązek właściwego ustalenia wymiaru opodatkowania.

Jak podkreślano dotychczas, zmiana nieprawidłowych informacji w ewidencji odbywać się powinna w toku odrębnego postępowania przed organem prowadzącym ewidencję ${ }^{44}$, niezależnie od postępowania związa-

40 Zob. szerzej o pracownikach samorządowych: J.M. Zieliński, „Służq̨c wspólnocie samorzq̨dowej” - z problematyki prawa pracowników samorzq̨dowych, „Samorząd Terytorialny”, 2014, nr 7-8, s. 77-84.

41 Zob. L. Etel, Podatek o nieruchomości. Komentarz, Warszawa 2012, s. 99. Potwierdza to także wyrok SN z dnia 13 lutego 2003 r., III RN 21/02, LEX nr 1130942.

42 Ustawa z dnia z dnia 29 sierpnia 1997 r. Ordynacja podatkowa (tekst jedn. Dz.U z 2015 r., poz. 613 ze zm., zwana dalej o.p.).

43 Zob. Wyrok WSA w Łodzi z dnia 24 listopada 2004 r., I SA/Łd 612/04, LEX nr 809582.

44 W. Morawski, Znaczenie danych zawartych $w$ ewidencji gruntów dla ustalenia podstawy opodatkowania. Podatek od nieruchomości, [w:] W. Morawski (red.), 
nego z wymiarem podatku przez co do zasady inny, jednak w praktyce niejednokrotnie ten sam organ (chodzi tutaj o prezydenta miasta na prawach powiatu). W orzecznictwie sądów administracyjnych funkcjonuje bowiem pogląd, że zarzucenie organom podatkowym błędnych ustaleń co do powierzchni gruntów jest niemożliwe, dopóki nie zostanie zakończone postępowanie ws. zmian zapisów w ewidencji ${ }^{45}$. Tego rodzaju pogląd w zestawieniu z art. 194 o.p., który mówi, że „Dokumenty urzędowe (...) stanowią dowód tego, co zostało w nich urzędowo stwierdzone”, stawia podatnika, którego grunt został niewłaściwie zaklasyfikowany w ewidencji, w bardzo trudnej sytuacji względem organu podatkowego. Istnieje bowiem domniemanie prawdziwości ewidencji, niezależnie od informacji, jakie zawiera. Tego rodzaju usztywnienie zależności między wymiarem podatku a zapisami w ewidencji może prowadzić do sytuacji, w której koszty ekonomiczne niewłaściwego prowadzenia rejestru ponoszą podatnicy lub gminy, a starostowie lub prezydenci miast w przewidzianym dla siebie trybie dokonują aktualizacji w toku odrębnego postępowania bądź okresowej aktualizacji.

Pozytywną zmianą w praktyce ustalania wymiaru podatków przez organy podatkowe może być przyjęcie, że zapis w ewidencji nie zawsze odzwierciedla rzeczywisty stan faktyczny. Sądzę, że organy podatkowe nie są w sposób nieograniczony związane danymi w ewidencji, a mogą wziąć pod uwagę wskazanie podatnika na występowanie oczywistych błędów zawartych w operacie. Tego rodzaju działanie wymaga dokładnej analizy zapisów rejestru oraz dokumentów związanych z ustaleniem rozbieżności w ustaleniu powierzchni gruntów ${ }^{46}$. Takie postępowanie organów podatkowych wymaga także zmiany polityki administracji samorządowej w zakresie podejścia do podatników i przejścia ze stosunku biurokratycznego do partnerskiego traktowania interesantów, w zakresie

Podatek od nieruchomości w orzecznictwie sqdów administracyjnych. Komentarz. Linie interpretacyjne, Warszawa 2013, s. 426-427.

45 Potwierdza to wyrok WSA w Lublinie z dnia 1 grudnia 2006 r., I SA/Lu 507/06; tamże, s. 426.

46 Zob. wyrok WSA w Olsztynie z dnia 8 grudnia 2004 r., I SA/Ol 298/04; tamże s. 427-428. 
współpracy i otwartości na dialog oraz stosowanie prawa z uwzględnieniem interesu obywatelskiego.

Inną kwestią jest obowiązek poinformowania podmiotu ujętego w ewidencji o zmianie danych zawartych w ewidencji. Zachodzić może bowiem sytuacja, w której podatnik przez nawet 15 lat płacił podatek rolny, którego stawki są bardziej korzystne dla podatnika, niż stawki podatku od nieruchomości, jednak w wyniku aktualizacji danych w ewidencji, grunt może zostać oznaczony jako inny niż ten, który podlega podatkowi rolnemu (a nie podatkowi od nieruchomości). Tego rodzaju sytuacja może skutkować znacznym zwiększeniem obciążenia fiskalnego podatnika i naruszeniem jego stabilności finansowej.

\section{Podsumowanie}

Określanie podstawy opodatkowania przy podatkach od majątku nieruchomego jest niezbędne do ich prawidłowego funkcjonowania oraz przewidywalności wpływów do budżetów samorządowych. Ewidencja gruntów i budynków, która jest narzędziem służącym do określania tej podstawy, ma jednak pewne wady.

Za pierwszą z nich można uznać wskazanie organu, na którym ciąży odpowiedzialność za prowadzenie ewidencji, który w określonych przypadkach może być jednocześnie organem podatkowym. Wyznaczenie organów samorządowych jako władnych do prowadzenia ewidencji budzi wątpliwości. Administracja samorządowa może dysponować gorszym wsparciem teleinformatycznym i specjalistycznym w zakresie realizowania tej funkcji, niż np. terenowa administracja rządowa.

Reformy wymaga też jawność dostępu do ewidencji. Jak wskazują przepisy oraz praktyka, dane dostępne są na wniosek osoby zainteresowanej, a wszystkie odpisy realizowane są odpłatnie. Z jednej strony argumentować to można ochroną danych i przynajmniej częściową rekompensatą kosztów prowadzenia tego narzędzia przez administrację. Z drugiej natomiast, zmiany w ewidencji mogą pojawiać się w sposób nieoczekiwany. Dane o klasyfikacji poszczególnych nieruchomości, bez podawania 
informacji szczegółowych, powinny być osiągalne dla podatnika w wolnym dostępie do systemu informatycznego.

Elementem, o którym warto wspomnieć, jest brak szczegółowego określenia zasad dotyczących aktualizacji danych zawartych w ewidencji. Obecna praktyka wskazuje na przekazywanie osobom znajdującym się w zależności służbowej w stosunku do organu podatkowego, zadań w zakresie oceny dokumentacji i stanu faktycznego. O ile ocena dokumentacji mieści się w przedziale standardowych kompetencji pracowników urzędów samorządowych, to wątpliwości mogą budzić kompetencje tych urzędników w zakresie oceny klasyfikacji nieruchomości oraz gruntów rolnych i leśnych.

Powyższe rozważania wskazują na potrzebę zmian w funkcjonowaniu ewidencji potrzebnej do określania podatków od nieruchomości, rolnego i leśnego. Sama koncepcja oparcia się o tego rodzaju ewidencję wydaje się słuszna, jednak niedostosowana do warunków drugiej dekady XXI wieku.

\section{Bibliografia:}

Banasik P., Sarna A., Opodatkowanie podatkiem od nieruchomości dróg wewnętrznych, „Przegląd Podatkowy” 2007, nr 11, s. 43-48.

Baran B., Prawo cywilne dla zarzq̨dców nieruchomości, Wolters Kluwer, Warszawa 2009.

Borodo A., Podatki majq̨tkowe w Polsce - zagadnienia ogólne, [w:] H. Dzwonkowski, J. Głuchowski, A. Pomorska (red.), W kręgu prawa podatkowego i finansów publicznych. Księga dedykowana Profesorowi Cezaremu Kosikowskiemu w 40-lecie pracy naukowej, Wydawnictwo UMCS, Lublin 2005.

Borkowski P., Kataster nieruchomości, [w:] P. Borkowski, Notarialne poświadczenie dziedziczenia, LexisNexis, Warszawa 2011.

Chojna-Duch E., Kształtowanie podstawy opodatkowania podatkiem od nieruchomości, „Samorząd Terytorialny” 1992, nr 3, s. 10-16.

Etel L., Podatek o nieruchomości. Komentarz, Wolters Kluwer, Warszawa 2012.

Hanusz A., Podatek od nieruchomości, [w:] A. Hanusz (red.), Źródła finansowania samorzqdu terytorialnego, Wolters Kluwer, Warszawa 2015. 
Miemiec W., Finanse samorzqdu terytorialnej w nowej Konstytucji Rzeczypospolitej Polskiej, „Finanse Komunalne” 1997, nr 5, s. 5-14.

Morawski W., Znaczenie danych zawartych w ewidencji gruntów dla ustalenia podstawy opodatkowania. Podatek od nieruchomości, [w:] W. Morawski (red.), Podatek od nieruchomości w orzecznictwie sq̨ów administracyjnych. Komentarz. Linie interpretacyjne, Wolters Kluwer, Warszawa 2013.

Ostrowski K., Prawo finansowe. Zarys ogólny, PWN, Warszawa 1970.

Rogalska B., Podatkowe rejestry podmiotowe o charakterze podstawowym, [w:] Rogalska B., Podatkowe rejestry podmiotowe w polskim systemie prawnym, Wolters Kluwer, Warszawa 2014.

Zieliński J.M., „Służq̨c wspólnocie samorzq̨dowej” - z problematyki prawa pracowników samorzq̨dowych, „Samorząd Terytorialny” 2014, nr 7-8, s. 77-84. 